\title{
CAMERA-TRAP MONITORING OF AMUR TIGER (PANTHERA TIGRIS ALTAICA) IN SOUTHWEST PRIMORSKY KRAI, 2013-2016: PRELIMINARY RESULTS
}

\author{
Dina S. Matiukhina ${ }^{1}$, Anna V. Vitkalova ${ }^{1}$, Alexander N. Rybin ${ }^{2}$, \\ Vladimir V. Aramilev ${ }^{3}$, Elena I. Shevtsova ${ }^{1}$, Dale G. Miquelle ${ }^{2,4}$ \\ ${ }^{1}$ United Administration of the State Nature Biosphere Reserve «Kedrovaya Pad» \\ and «Land of the Leopard» National Park, Russia \\ e-mail:matiukhina@leopard-land.ru \\ ${ }^{2}$ Wildlife Conservation Society, Russia Program, USA \\ e-mail:dmiquelle@wcs.org \\ ${ }^{3}$ Institute of Sustainable Use of Natural Resources, Russia \\ e-mail: aramilev@yandex.ru \\ ${ }^{4}$ Far Eastern Federal University, Russia
}

Received: 16.09 .2016

\begin{abstract}
Southwest Primorsky Krai retains the sole remaining population of critically endangered Amur leopards, but and also holds an isolated population of Amur tigers. This small group of tigers plays a key role as a core breeding population for potential Amur tiger recovery in neighboring Jilin and Heilongjiang Provinces of Northeast China. A large scale camera-trap monitoring program initiated by the United Administration of the State Nature Biosphere Reserve Kedrovaya Pad and Land of the Leopard National Park in 2013 provides a more precise means of tracking dynamics of animals' abundance than previous snow-track counts and is to act «early warning system» in a case of dramatic decreases in tiger numbers. Surveys were conducted over three years, beginning in August 2013 and ending in July 2016. During each survey year, we planned to select a survey period of no more than 92 days when no less than $80 \%$ of camera-trap stations were active. However, as the camera-trap stations were not simultaneously deployed and checked during the last year (2015-2016), using the 80\% cut point substantially was not feasible, so we lowered the limit to $55 \%$. To estimate detection rates for adults, we used only those animals that were present in a given year both before and after the survey period, with the assumption that if a tiger were present both before and after, most likely it was present during the survey period as well. From the 320 photographic captures obtained over three years we identified 39 adult Amur tigers and 22 cubs. Among them only seven adult individuals (18\%) were captured in all three years, while sixteen adult individuals (41\%) were captured only in one of the three years; the rest $(41 \%)$ were captured in two of the three years. Females demonstrate greater fidelity, and a greater likelihood or being present in all three years. Tigers were more frequently captured during the cold season from October to March with the peak numbers recorded in December. However, there were only ten instances in which adult/subadult tigers were photographed both before and after the survey period in all years combined. Of those, in only six instances $(60 \%)$ tigers also photographed during the survey period, suggesting a relatively low detection probability. However detection of cubs was even lower: twenty-two cubs were photographed during the three years of the study but only three (14\%) were photographed during the three survey periods. These results suggest that capture rates of cubs are much lower than those of adults/subadults reaffirming recommendations to not include cubs in formal population abundance estimates.
\end{abstract}

Key words: Amur tiger, camera-trapping, detection rate, Land of the Leopard National Park, southwest Primorsky Krai.

\section{Introduction}

Southwest Primorsky Krai is home to the last remaining wild population of critically endangered Amur leopards (Panthera pardus orientalis, Schlegel, 1857) (IUCN Red List, Version 3.1., 2014) and a small subpopulation of endangered Amur tigers (Panthera tigris altaica, Temminck, 1844), which represents about 5\% of the entire Amur tiger population.

Development of a protected areas network to conserve Amur leopards started in the mid-1970's, and culminated with the creation of Land of the Leopard National Park in 2012. At present, the area of the Park, combined with Kedrovaya Pad State Nature Biosphere Reserve, totals $2,800 \mathrm{~km}^{2}$, and provides protection for approximately $60 \%$ of suitable habitat for both species in Southwest Primorye.

The mission of the national park is to conserve and recover the population of Amur leopards using scientifically based conservation principles. While conservation of Amur leopards is of primary con- 
cern, their fate is closely linked to that of the Amur tigers co-occupying the park, which are also of high conservation importance. Tigers in Southwest Primorye are separated from the main tiger population in the Sikhote-Alin Mountains by a development corridor between the two major cities of Vladivostok and Ussuriysk (Darman \& Williams, 2003; Miquelle et al., 2015). This anthropogenic barrier has limited dispersal of large carnivores and resulted in a genetically distinct tiger population in southwest Primorye (Henry et al., 2009; Sorokin et al., 2015). Although a few migrants from southern SikhoteAlin have been identified in southwest Primorsky Krai, it is still unknown whether these occasional migrants have successfully contributed to the gene pool of the southwestern sub-population (Henry et al., 2009). Further disruption of tiger movements between two landscapes may have serious consequences for genetic health of the smaller group of tigers, and limits the potential for expansion of the leopard population.

As part of the Russian Far East - China Global Priority Tiger Conservation Landscape (TCL) (Dinerstein et al. 2006) the Land of Leopard National Park is of crucial importance as a core breeding site for Amur tiger recovery in neighboring Jilin and Heilongjiang Provinces of Northeast China (Miquelle et al., 2015). Further expansion of both Amur tiger and leopard populations in southwest Primorsky Krai is unlikely since they currently occur in all suitable habitat, and further expansion is limited by surrounding agricultural and infrastructure development. Thus the contiguous Hunchun - Wangqing area of Jilin Province, China, which has large patches of suitable habitat, represents the best opportunity for recolonization and expansion of both large felid populations (Hebblewhite et al., 2012; Wang et al., 2016). Over the past decade the number of Amur tiger records in China, including breeding females, has been increasing (Xiao, 2015; Wang et al., 2016). However, the future of tiger recovery in China still heavily depends on the southwest Primorye core population, as evidenced by the fact that most tigers recorded in China occur in close proximity to the international border (Wang et al., 2016).

Regular and accurate monitoring of these populations is critical to detect changes in population size and/or structure, and to act as an «early warning system» to detect dramatic declines in population size. However, traditional monitoring techniques, based on interpreting the number of animals on the basis of track counts in snow, are fraught with difficulties, most notably that their accuracy is unknown, resulting in considerable variation in interpretation of results (e.g. Pikunov et al., 2009; Aramilev V.V.
\& Aramilev S.V., 2013). Properly designed camera trap surveys bypass many of these problems by providing statistically robust estimates of abundance and error, plus provide a means of identifying individuals crossing international boundaries.

The most robust population estimates derived from camera trap data apply mark-recapture analyses (Karanth \& Nichols, 2002, 2006) that assume that not all individuals were photographed, and consequently attempt to estimate population size based on detection probabilities. The methodology has been thoroughly described and successfully tested in Russia (Kostyria et al., 2003; Aramilev et al., 2010; Soutyrina et al., 2013). The great value of this approach is its statistical robustness and its ability to provide an estimate of statistical error associated with the population estimator. However, there are two conditions for conducting such surveys that are, to some extent at odds with each other. On the one hand, surveys must be sufficiently short to ensure that the population is «closed»: that is, there is no immigration, emigration, mortality, or births during the survey period. This is an assumption of not only camera trap surveys, but any method designed to estimate animal abundance. The other condition is that multiple «captures» of individuals is necessary to accurately estimate detection probability and provide a small confidence interval. The first condition demands that surveys be as short as possible (to ensure population closure), while the second demands that surveys be as long as possible to increase sample size. The problem faced by anyone implementing such a survey is to balance these two demands.

Increasing the number of captures can be done not only by increasing the amount of time camera traps are active, but by placing camera traps in locations that maximize chances of photographing animals, by conducting surveys when capture rates are greatest, by increasing camera trap density, and by increasing survey duration. Applying these principles should allow one to reduce survey length, reducing the chances of violating the assumption of population closure. Karanth \& Nichols (2002) suggested that tiger surveys using mark-recapture approach should not exceed 60 days to ensure population closure. Soutryina et al. (2013) extended survey period to 90 days because capture rates were low in Sikhote-Alin Biosphere Nature Reserve.

Camera trap data also provides information on sex and age structure of populations, although identification of sex is not always possible. Additionally, it has been recommended that cubs not be included in mark-recapture estimates of tiger populations because they are rarely and inconsistently captured by camera traps (Karanth \& Nichols, 2002). Whether 
these recommendations hold for northern populations of tigers is still unclear.

Monitoring of small portions of Southwest Primorye has been conducted using camera traps since 2003 (Kostyria et al., 2003; Rybin et al., 2015). In 2013, the United Administration of the State Nature Biosphere Reserve Kedrovaya Pad and Land of the Leopard National Park initiated large scale camera trap surveys over the entirety of suitable large felid habitat. Here we present preliminary results from 2013-2016 to determine «best practices» for organizing yearly surveys of Amur tigers in the Land of Leopard National Park. Specifically, we attempted to do the following:

1. Establish a camera trap network year-round to determine the best season for camera trapping (i.e., to determine when capture rates are greatest).

2. Assess sex-age structure of the population and develop a crude estimate of site fidelity by looking at what proportion of the years each animal was present in the study site, and comparing those proportions between the sexes.

3. Assess how capture rates varied among years.

4. Develop a crude estimate «detection rates» of adults and cubs to determine whether there is variation between cubs and adults, as reported by Karanth \& Nichols (2002).

\section{Material and Methods}

We used digital camera traps $\left(\right.$ Reconyx ${ }^{\mathrm{TM}}$, ScoutGuard $^{\mathrm{TM}}$, Bestok ${ }^{\mathrm{TM}}$, Bushnell ${ }^{\mathrm{TM}}$ ) equipped with motion and infrared sensors.

The Park was divided into two primary monitoring units. The first included only the territory of border control zone. This narrow strip of land $\left(1200 \mathrm{~km}^{2}\right)$ stretches north to south along the Russian-Chinese border and varies from 1 to $12 \mathrm{~km}$ wide. Pairs of camera-traps (to photograph both sides of an animal) were placed at stations in the border patrol zone to be functional year-round, with battery exchanges and data collection occurring twice a year. The second monitoring unit of $2400 \mathrm{~km}^{2}$ included the rest of the Park area and a large proportion of its buffer zone. Camera-trap stations in this monitoring unit were set up seasonally from mid-winter to mid-summer.

Camera-traps were deployed at sites where the probability of Amur leopard capture is highest, based on known movement corridors and habitat preferences relative to elevation and relief. Despite the fact that placement of camera traps was targeted at photographing Amur leopards, Amur tigers were also commonly photographed.

Single or multiple photographs of a single tiger made at one site over a 24 hour period were considered a single «capture». Identification of individual tigers was conducted using ExtractCompare computer software (Conservation Research Ltd., UK). The software operates on a Microsoft Access platform enabling the storage of camera trap data as well as database management.

Surveys were conducted over three years, beginning in August 2013 and ending in July 2016. During each survey year, we planned to select a survey period of no more than 92 days when no less than $80 \%$ of camera-trap stations were active. However, as the camera-trap stations were not simultaneously deployed and checked during the last year (20152016), using the $80 \%$ cut point substantially was not feasible, so we lowered the limit to $55 \%$ (Table 1).

Table 1. Number of camera-trap stations per year, dates of survey, number of days of survey, number of camera trap days per year and study period, number of captures of adults and cubs per year and study period, and capture rate (captures/1000 trap days)

\begin{tabular}{|c|c|c|c|c|c|c|c|c|c|}
\hline \multirow{3}{*}{$\begin{array}{l}\text { Survey } \\
\text { years }\end{array}$} & \multirow{3}{*}{$\begin{array}{c}\text { Number of } \\
\text { camera-trap } \\
\text { stations }\end{array}$} & \multirow{3}{*}{$\begin{array}{c}\text { Survey } \\
\text { period dates }\end{array}$} & \multirow{3}{*}{$\begin{array}{l}\text { Number } \\
\text { of days } \\
\text { / survey } \\
\text { period }\end{array}$} & \multicolumn{2}{|c|}{ Camera-trap days } & \multicolumn{2}{|c|}{ Number of captures } & \multicolumn{2}{|c|}{$\begin{array}{c}\text { Capture rate (captures / } \\
1000 \text { trap days) }\end{array}$} \\
\hline & & & & & & (adu & and cubs) & $(\mathrm{ad}$ & s and cubs) \\
\hline & & & & /Year & $\begin{array}{l}\text { /Survey } \\
\text { period }\end{array}$ & /Year & $\begin{array}{l}\text { /Survey } \\
\text { period }\end{array}$ & /Year & /Survey period \\
\hline 2013-2014 & 151 & $\begin{array}{l}20.03 .2014 \\
31.05 .2014 \\
\end{array}$ & 73 & 27948 & 9956 & 103 & 26 & 3.69 & 2.61 \\
\hline 2014-2015 & 165 & $\begin{array}{l}09.02 .2015 \\
22.04 .2015\end{array}$ & 73 & 31428 & 10837 & 135 & 71 & 4.30 & 6.55 \\
\hline 2015-2016 & 132 & $\begin{array}{l}15.01 .2016 \\
15.04 .2016 \\
\end{array}$ & 92 & 20745 & 7885 & 82 & 41 & 3.95 & 5.20 \\
\hline Average & 149 & & 79 & 26707 & 9559 & 107 & 46 & 3.98 & 4.79 \\
\hline
\end{tabular}


To assess which seasons are best for surveying tigers, we used data only from the border control monitoring unit to estimate the number of captures that occurred in each month over the three years.

We attempted to identify sex of animals based on the presence of external genitalia when photographs provided a view of the rear side of an animal. Body size and relative head size provided additional clues to determine sex of an animal. To assess site fidelity, we summarized the number of years each individual was present on the study area, and compared the proportion of each sex present for one, two, or all three years.

To estimate detection rates for adults, we used only those animals that were present in a given year both before and after the survey period, with the assumption that if a tiger were present both before and after, most likely it was present during the survey period as well. We defined detection rate as the number of animals observed in all three periods (before, during, after survey period) compared to all animals detected before and after the survey period. For cubs, we compared the number of cubs captured during the study period versus the number captured before or after the survey period.

\section{Results and Discussion}

We obtained 3091 images of Amur tigers representing 320 captures over the three year period. An average 26707 trap days were conducted using an average 149 pairs of camera traps (Table 1). Capture rate per year varied only slightly (3.69-4.30 captures/1000 trap days) while capture rate of the shorter survey periods varied more (2.61 to 6.55 captures/1000 trap days)/.

Tigers were more frequently captured during the cold season from October to March with the peak numbers recorded in December. A gradual decrease in capture numbers was noticeable from April to September. These results clearly suggest that surveys should be conducted in the late fall-winter period to maximize the number of captures.

From the 320 photographic captures obtained over three years we identified 39 adult Amur tigers and 22 cubs. Among them only seven adult individuals $(18 \%)$ were captured in all three years, while sixteen adult individuals (41\%) were captured only in one of the three years; the rest (41\%) were captured in two of the three years. Females were more likely to be captured in all three years, while males were more likely to be captured only in one year (Fig. 2). This observation coincides with reports of higher mortality rates of males, and longer dispersal distances (Robinson et al., 2015; Goodrich et al., 2010), both of which would reduce the likelihood of males being present in all three years compared to females.

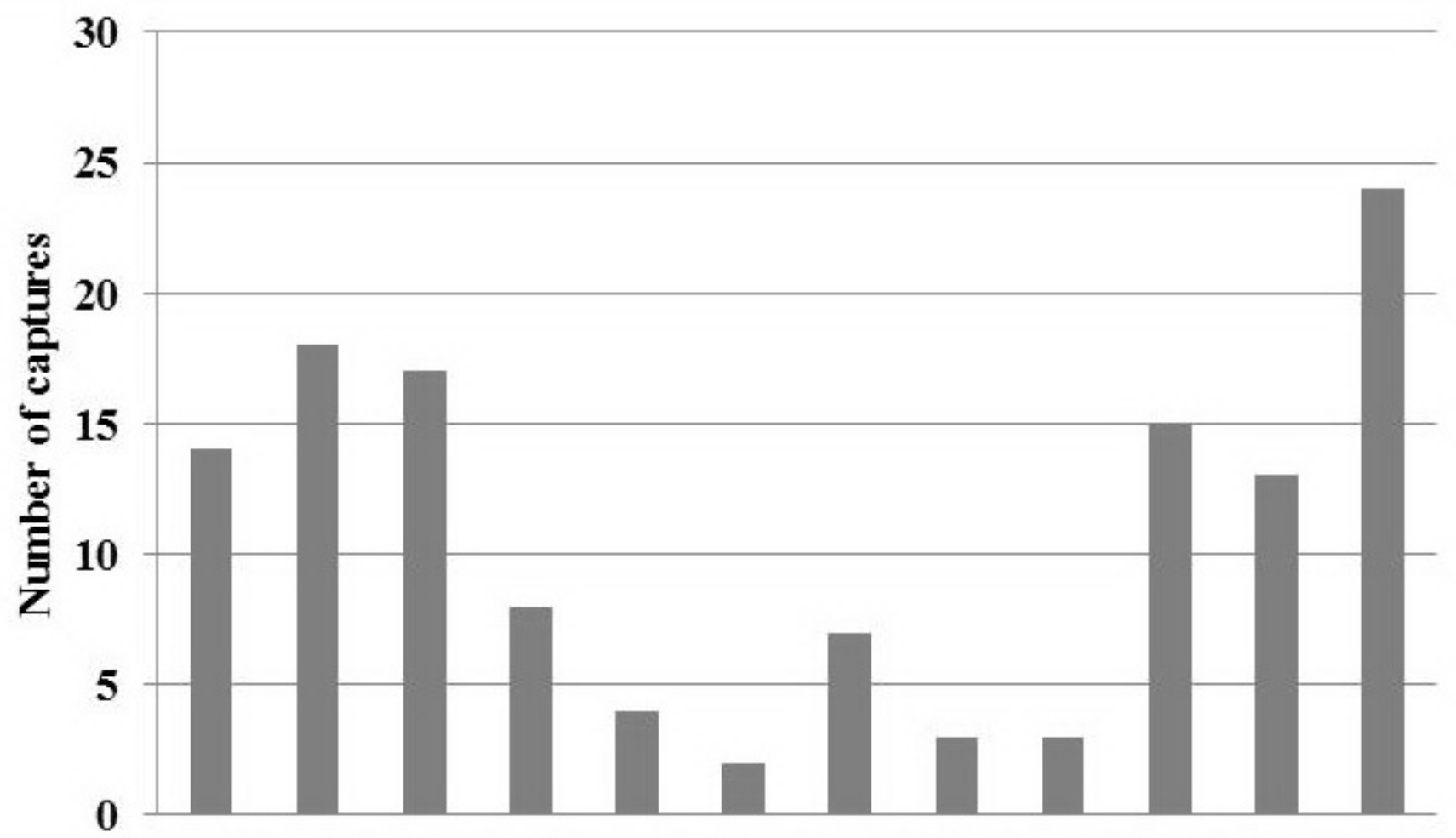

Jan Feb Mar Apr May June July Aug Sep Oct Nov Dec

Month

Fig. 1. The number of Amur tiger photographic captures per month based on data obtained from the border control zone of Land of the Leopard National Park, 2013-2016. 
$60 \%$

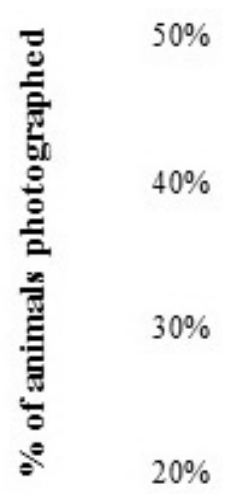

$20 \%$

$10 \%$

$0 \%$

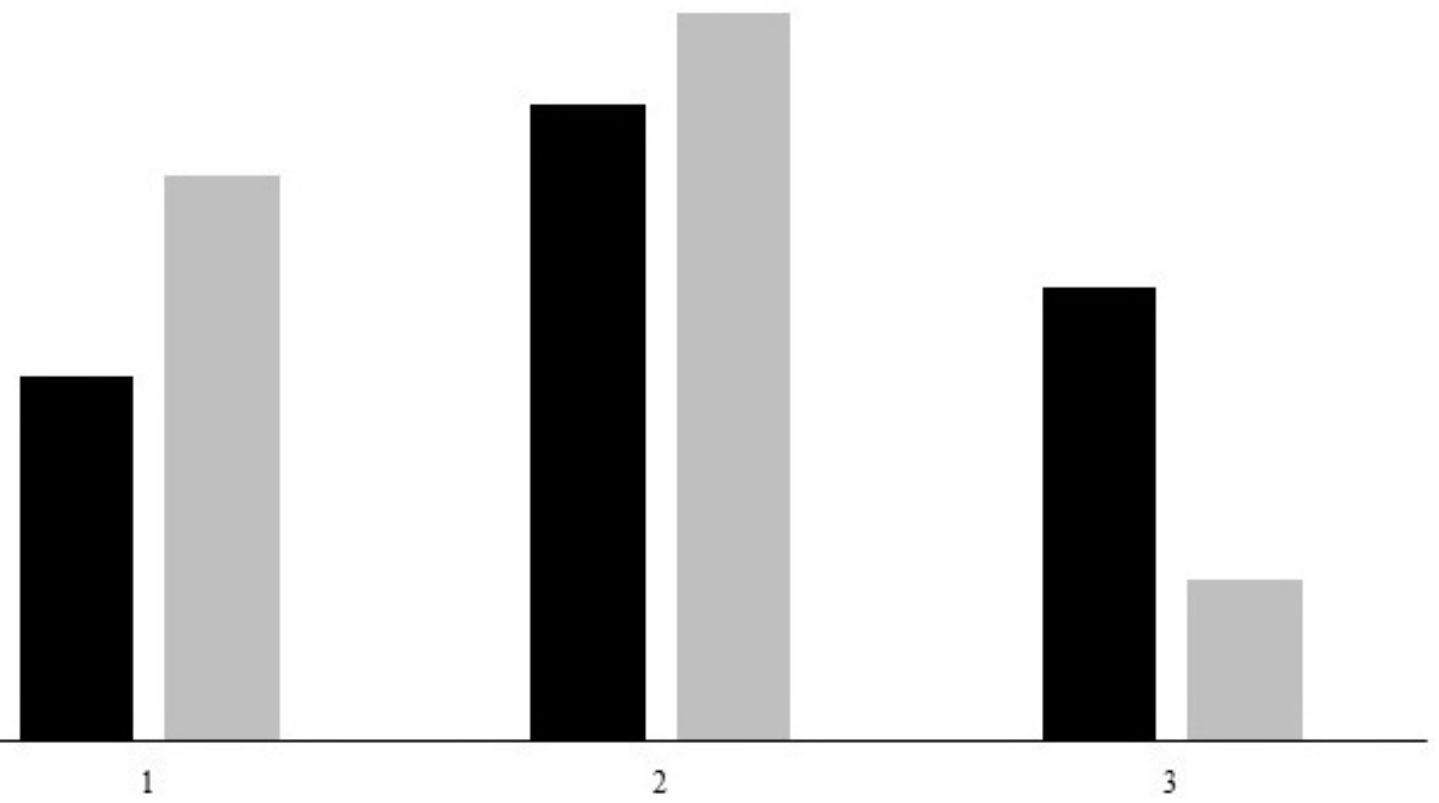

Years Present

- Females Males

Fig. 2. The percentage of female and male tigers photographed in only one, two, or all three years of camera trapping in Land of the Leopard National Park, 2013 through 2016.

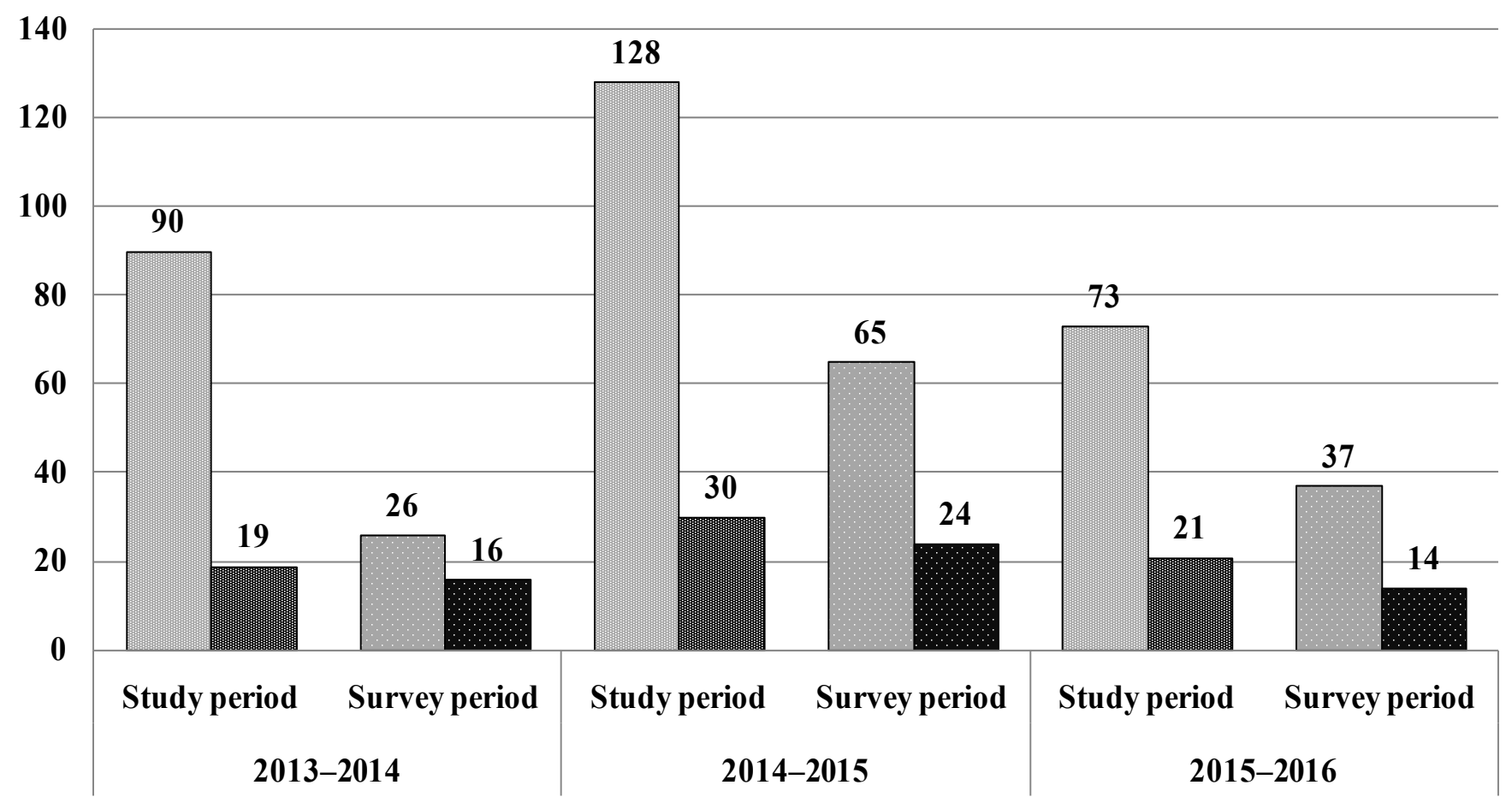

$\square$ Number of captures $\quad$ Number of individuals

Fig. 3. Changes in the number of adult and sub adult Amur tigers identified relative to the number of captures within each study period. 
The fewest number of adults (19) were observed in the first year (2013-2014), coinciding with the lowest capture rates (Table 1). However, despite the low capture rate, a large proportion $(84 \%)$ of tigers captured during the year were also captured during the survey period. The highest capture rate occurred during the second survey period, when half of the captures of the entire year were made in that 73-day period (Fig. 3).

Extending the survey period in 2015-2016 to 92 days resulted in an increase in the number captures (37), but the number of individuals recorded (14) was the lowest of the three years. The lower number of camera-trap stations deployed during 2015-2016 along with non-simultaneous deployment of camera traps likely also reduced the number of tigers captured and the overall number of captures.

Comparisons between survey years and survey periods (Fig. 2) are not all that informative because it is not known if the animals observed at other times of the year were present during the survey period. If animals were present both before and after the survey period, in all likelihood they were present on the study site during the survey as well. However, there were only ten instances in which adult/sub-adult tigers were photographed both before and after the survey period in all years combined. Of those, in only six instances $(60 \%)$ tigers also photographed during the survey period, suggesting a relatively low detection probability. However detection of cubs was even lower: twenty-two cubs were photographed during the three years of the study but only three (14\%) were photographed during the three survey periods (Table 2 ). These results suggest that capture rates of cubs are much lower than those of adults/subadults.

\section{Conclusions}

The survey design employed over the three years of study appeared adequate to obtain suffi-

Table 2. Number of litters and cubs «captured» on camera traps during an entire year and during a restricted survey period in Land of the Leopard National Park, 2013-2016

\begin{tabular}{|c|c|c|c|}
\hline \multirow{2}{*}{$\begin{array}{c}\text { Study } \\
\text { period }\end{array}$} & \multirow{2}{*}{ Number of litters } & \multicolumn{2}{|c|}{ Number of cubs } \\
\cline { 3 - 4 } & & Year & Survey period \\
\hline $2013-2014$ & 3 & 11 & 0 \\
\hline $2014-2015$ & 3 & 4 & 1 \\
\hline $2015-2016$ & 3 & 7 & 2 \\
\hline
\end{tabular}

ciently large numbers of photographic captures of tigers. However, it is clear that in 2015-2016, an inappropriate sampling schedule reduced or delayed the amount of information acquired, which in turn will weaken the mark-recapture analyses and reduce our ability to detect trends in the population of tigers in Land of the Leopard National Park. It is recommended that future yearly efforts be maintained at an agreed upon minimum level and that camera traps must operate simultaneously during a 60 to 90 day period, preferably in late fall and winter. As observed elsewhere, litters were poorly captured on film, and hence we agree that it is best to exclude cubs from the formal mark-recapture analysis, as poor detection and poor recapture rates will reduce the accuracy of the overall estimate.

Females demonstrate greater fidelity, and a greater likelihood or being present in all three years. Monitoring the female segment of the population is very useful, as reproduction rates are the key determinant of population growth rates. Monitoring the longevity of females in Land of the Leopard National Park will provide an index of population health.

Increasing the number of photographic captures of tigers can be done not only by increasing the amount of time camera traps are active, but by placing camera traps in locations that maximize chances of photographing tigers, by conducting surveys when capture rates are greatest (fallwinter), and by increasing camera trap density. Currently nearly all camera traps are positioned to maximize probability of photographing leopards. We believe that it would be wise to allocate a small proportion of camera traps (possible 20$30 \%$ ) to locations where the probability of photographing tigers is greater. Although these locations (often trails and forest roads) make the risk of theft of camera traps greater, it is possible to camouflage camera trap locations. This change in priorities could greatly increase the photographic capture rate of tigers in Land of the Leopard National Park, and increase survey accuracy.

Applying these recommendations should allow us to increase capture rate, and keep survey length sufficiently small to reduce the chances of violating the population closure assumption. Karanth \& Nichols (2002) suggested that tiger surveys using mark-recapture approach should not exceed 60 days to ensure population closure. Soutryina et al. (2013) extended survey period to 90 days because capture rates were low in SikhoteAlin Biosphere Nature Reserve. We will seek to keep survey length in this 60-90 day period. 
Intensifying the monitoring program in the Land of Leopard National Park would significantly broaden our understanding of the ongoing processes in populations of both Amur leopards and tigers and provide important clues as to how to allocate the Park's resources and where the conservation activities should be focused to effectively manage the entire ecosystem.

\section{Acknowledgements}

We thank staff of the Scientific and Law Enforcement Departments of the United Administration of the State Nature Biosphere Reserve Kedrovaya Pad and Land of the Leopard National Park for organizing the monitoring program and conducting the field work. We appreciate the camera-trap data contributed by the Park's collaborators Dale G. Miquelle and Alexander Rybin (Wildlife Conservation Society, Russia Program) and Vladimir V. Aramilev (Institute of Sustainable Use of Natural Resources). This work was supported by Autonomous Nonprofit Organization «Far Eastern Leopards» and Russian Geographical Society.

\section{References}

Aramilev V.V., Aramilev S.V. 2013. Report on the 2013 survey of Far Eastern Leopards. Unpublished report.

Aramilev V.V., Kostyria A.V., Sokolov S.A., Rybin A.N., McCullough D., Miquelle D.G. 2010. Monitoring of Far-Eastern leopard (Panthera pardus orientalis) population with photo traps. In: Proceedings of the International Conference. The Amur Tiger in Northeast Asia: Planning for the $21^{\text {st }}$ Century. Vladivostok: Dalnauka. P. 343-352. [In Russian]

Darman Y., Williams L. 2003. Conservation Action Plan for the Russian Far East Ecoregion Complex. Part 2. NGO Joint Action Plan. Vladivostok: WWF.

Dinerstein E., Loucks C., Heydlauff A., Wikramanayake E., Bryja G., Forrest J., Ginsberg J., Klenzendorf S., Leimgruber P., O'Brien T., Sanderson E., Seidensticker J., Songer M. 2006. Setting Priorities for the Conservation and Recovery of Wild Tigers: 2005-2015. A User's Guide. Washington, D.C.; New York: WWF, WCS, Smithsonian and NFWF-STF.

Goodrich J.M., Miquelle D.G., Smirnov E.N., Kerley L.L., Quigley H.B., Hornocker M.G. 2010. Social structure of Amur (Siberian) tigers (Panthera tigris altaica) on Sikhote-Alin Biosphere Zapovednik, Russia. Journal of Mammalogy 91 (3): 737-748.

Hebblewhite M., Zimmermann F., Li Z., Miquelle D.G., Zhang M., Sun H., Mörschel F., Wu Z., Sheng L., Purekhovsky A., Chunquan Z. 2012. Is there a future for Amur tigers in a restored tiger conservation landscape in Northeast China? Animal Conservation 15 (6): 579-592.
Henry P., Miquelle D., Sugimoto T., McCullough D.R., Caccone A., Russello M.A. 2009. In situ population structure and ex situ representation of the endangered Amur tiger. Molecular Ecology 18: 3173-3184.

Karanth K.U., Nichols J.D. 2002. Monitoring tigers and their prey: A Manual for Researches, Managers and Conservationists in Tropical Asia. Bangalore: Centre for Wildlife Studies. $193 \mathrm{p}$.

Kostyria A.V., Skorodelov A.S., Miquelle D.G., Aramilev V.V., McCullough D. 2003. Results of camera trap survey of Far Eastern Leopard Population in southwest Primorski Krai, winter 2002-2003. Final report. Vladivostok. 22 p.

Miquelle D.G, Rozhnov V.V., Ermoshin V., Murzin A.A., Nikolaev I.G., Hernandez-Blanco J.A., Naidenko S.V. 2015. Identifying ecological corridors for Amur tigers (Panthera tigris altaica) and Amur leopards (Panthera pardus orientalis). Integrative Zoology 10: 389-402.

Pikunov D.G., Seryodkin I.V., Aramilev V.V., Nikolaev I.G., Murzin A.A. 2009. Large carnivores and ungulates in southwest Primorskii Krai. Vladivostok: Dalnauka. 95 p.

Robinson H.S., Goodrich J.M., Miquelle D.G., Miller C.S., Seryodkin I.V. 2015. Mortality of Amur tigers: the more things change, the more they stay the same. Integrative Zoology 10: 344-353.

Rybin A.N., Miquelle D.G., Storozhuk V.B., Matiukhina D.S. 2015. Report on a Survey of Far Eastern Leopards and Amur Tigers using camera traps in Southwest Primorskii Krai, winter 2015. Report to Land of the Leopard National Park. [In Russian]

Sorokin P.A., Rozhnov V.V., Krasnenko A.U., Lukarevskiy V.S., Naidenko S.V., Hernandez-Blanco J.A. 2016. Genetic structure of the Amur tiger (Panthera tigris altaica) population: Are tigers in Sikhote-Alin and southwest Primorye truly isolated? Integrative Zoology 11: 25-32.

Soutyrina S.V., Riley M.D., Goodrich J.M., Seryodkin I.V., Miquelle D.G. 2013. A population estimate of Amur tigers using camera traps. Vladivostok: Dalnauka. 156 p. [In Russian]

Wang T., Feng L., Mou P., Wu J., Smith J.L.D., Xiao W., Yang H., Dou H., . Zhao X., Cheng Y., Zhou B., Wu H., Zhang L., Tian Y., Guo Q., Kou X., Han X., Miquelle D.G., Oliver C.D., Xu R. 2015. Amur tigers and leopards returning to China: direct evidence and a landscape conservation plan. Landscape Ecology 31 (3): 491-503.

Wu Z., Jiang J., Lang J., Kong W., Liu P. 2013. Report of the Specific Survey to the Amur Leopard in the Southern Part of Laoyeling Range in Changbai Mountains, Jilin Province. Changchun: Jilin Science \& Technology Publishing House.

Xiao W., Feng L., Mou P., Miquelle D.G., Hebblewhite M., Goldberg J.F., Robinson H.S., Zhao X., Zhou B., Wang T., Ge J. 2016. Estimating abundance and density of Amur tigers along the Sino-Russian border. Integrative Zoology 11: 322-332. 


\title{
ФОТОМОНИТОРИНГ АМУРСКОГО ТИГРА НА ЮГО-ЗАПАДЕ ПРИМОРСКОГО КРАЯ, 2013-2016: ПРЕДВАРИТЕЛЬНЫЕ РЕЗУЛЬТАТЫ
}

\author{
Д. С. Матюхина ${ }^{1}$, А. В. Виткалова ${ }^{1}$, А. Н. Рыбин ${ }^{2}$, \\ В. В. Арамилев ${ }^{3}$, Е. И. Шевцова ${ }^{1}$, Д. Дж. Микелл ${ }^{2,4}$ \\ ${ }^{1}$ Объединенная дирекиия Государственного природного биосферного заповедника \\ «Кедровая падь» и начионального парка «Земля леопарда», Россия \\ e-mail:matiukhina@leopard-land.ru \\ ${ }^{2}$ Российское представительство Общества сохранения диких животных, США \\ e-mail:dmiquelle@wcs.org \\ ${ }^{3}$ Институт устойчивого природопользования, Россия \\ e-mail:aramilev@yandex.ru \\ ${ }^{3}$ Дальневосточный федеральный университет, Россия
}

\begin{abstract}
Юго-запад Приморского края имеет ключевое значение для сохранения единственной в мире популяции дальневосточного леопарда, а также изолированной группировки амурского тигра. Эта малочисленная группа тигров, в свою очередь, является единственным популяционным ресурсом для восстановления подвида в прилегающих провинциях КНР - Цзилинь и Хэйлунцзян. Масштабная программа фото мониторинга, организованная Объединенной дирекцией государственного природного заповедника «Кедровая падь» и национального парка «Земля леопарда» в 2013 году, дает возможность более точного отслеживания изменений численности животных по сравнению с предшествующими зимними учетами и должна действовать, как система раннего предупреждения в случае появления существенных негативных тенденций. Фото мониторинг проводился в период с августа 2013 года по июль 2016 г. Для каждого отдельно взятого года мы планировали выделить так называемый учетный период продолжительностью не более 92 дней, когда работало не менее $80 \%$ станций фото мониторинга. Однако в течение учетного периода 2015-2016 гг. часть станций фото мониторинга не была установлена или проверена одновременно с основным массивом станций. В данной ситуации использование показателя $80 \%$ работающих станций привело бы к существенному сокращению количества учетных дней, поэтому мы применили показатель в 55\%. Для оценки показателя обнаружения взрослых особей амурского тигра, мы использовали данные тех особей, которые были зарегистрированы до учетного периода и после него в течение каждого периода исследований. В данном случае мы предполагали, что если особь была зафиксирована до и после учета, то с большой долей вероятности животное присутствовало на территории исследования, но по каким-то причинам не было «отловлено» в период учета. Из 320 отловов амурского тигра, полученных в течение трех лет, мы идентифицировали 39 взрослых особей и 22 тигрят. Среди общего количества зарегистрированных взрослых тигров только 7 (18\%) отмечались ежегодно, в то время как 16 (41\%) особей были отмечены только в одном из трех периодов, а остальные 16 (41\%) отмечались, соответственно, в двух из трех. Большую часть особей, отмечавшихся ежегодно, составляли самки. Наибольшее количество фото отловов тигров было получено с октября по март на основании данных за трехлетний период, при этом, максимальное количество отловов приходилось на декабрь. В течение трех лет исследований было зарегистрировано только 10 случаев, когда взрослые и полувзрослые тигры отлавливались до и после учетного периода, в шести (60\%) из которых животные отмечались и в учетный период, что свидетельствует об относительно низком показателе обнаружения. Однако показатель обнаружения для тигрят был еще ниже и составлял 14\%. Наши результаты демонстрируют низкий показатель отловов для тигрят по сравнению с взрослыми и полувзрослыми особями тигра, что в свою очередь, подтверждает рекомендации других исследователей не включать тигрят при статистической оценке размера популяции.
\end{abstract}

Ключевые слова: амурский тигр, национальный парк «Земля леопарда», показатель обнаружения, фото мониторинг, юго-запад Приморского края. 